Гончаров В.В.

\title{
ГОСУДАРСТВЕННАЯ ВЛАСТЬ: ПОНЯТИЕ И СУЩНОСТЬ
}

\begin{abstract}
Аннотация: Настоящая статья посвящена анализу понятия и сущуности государственной власти через призму понятий «власть» и «государство». Дано авторское определение власти как философской и общесоииологической категории. В статье разработан категориальный аппарат исследования. Автором проведен анализ и оценка исторически сложившихся и современных различных отечественных и зарубежных концепций в определении понятия государственной власти, на основании которых предложена собственная авторская концепция определения понятия государственная власть. Изучены понятия системы государственной власти; системы государственных органов как совокупности законодательной (представительной), исполнительной, судебной власти через призму приничипа разделения властей. Проведено исследование сложивиихся в Российской Федерации ветвей государственной власти. Дань авторские определения понятий законодательной (представительной), исполнительной, судебной власти.
\end{abstract}

Review: The present article analyzes the definition and essence of state power from the point of view of the concepts 'power' and 'state institution'. The author of the article offers his own definition of power as a philosophical and general sociological concept. The article also describes the framework of research categories and concepts. The author analyzes and evaluates traditional and modern Russian and foreign concepts of state power. Based on those, the author offers his own concept and definition of state power. The author studies definitions of the system of state power, system of state authorities as a combination of legislative (representative), executive and judicial authorities from the point of view of the concept of separation of powers. The author also studies current branches of state power in the Russian Federation and offers his own definitions of legislative (representative), executive and judicial authorities.

Ключевые слова: Юриспруденция, государственная власть, право, полномочия, государственный аппарат, судебная власть, исполнительная власть, законодательная (представительная) власть, механизм, система

Keywords: study of law, state power, right, authorities, state machinery, judicial authority, executive authority, legislative (representative) authority, mechanism, system.

$\Pi$ онятие «государственная власть» производно от более широкого и многогранного понятия «власть». Однако последнее, в указанном аспекте, стало предметом специальной разработки в юридической литературе сравнительно недавно, примерно с начала 60-х годов, и нуждается в дальнейшем глубоком изучении.

Власть как философская и общесоциологическая категория представляет собой механизм существования и развития всякой социальной общности, соответствующее достигнутому характеру и уровню общественной жизни, характеризующееся подчинением воли отдельных субъектов властеотношения и их объединений (подвластных) руководящей (властвующей) в данном сообществе воле, подкрепленное возможностью принудительного ее исполнения. Данное определение характеризует

\footnotetext{
${ }^{1}$ Байтин, М.И. Государство и политическая власть. [Текст]
} - Саратов. - 1972. - С. 89 любой вид общественной власти: в обществе, в семье, и в государстве.

Рассмотрим теперь понятие «власть» в более узком смысле - через призму понятия «государство». В отечественной и зарубежной науке, трудах философов и государственных деятелей разработано множество подходов в определении понятия «государства» (нормативистский, теологический, естественно-правовой, культурологический и другие). 2 Некоторые учёные определяют государство как «основную политическую организацию классового общества, осуществляющую его управление, охрану его экономической и социальной структуры». ${ }^{3}$

\footnotetext{
${ }^{2}$ Кокорев, Р.С. Понятие и характерные черты государства как субъекта международного права [Текст] / Р.С. Кокорев // Государство и право. - 2005. - № 12. - С. 71-79.

${ }^{3}$ Ожегов, С.И. Словарь русского языка: ок. 57000 слов / Под ред. чл.-корр. АН СССР Н.Ю. Шведовой. 20-е изд., стереотип. [Текст] - М.: Русский язык, 1988. С. 115-116.
} 


\section{Политика и общество $7(103) \cdot 2013$}

По мнению других специалистов-филологов, государство - это «политическая организация общества во главе с правительством и его органами..., а также страна с такой политической организацией». ${ }^{4}$ В современной энциклопедической литературе государство в конституционном праве понимается как социально-политическая организация, действующая на определенной территории и обладающая на ней высшей властью. ${ }^{5}$

Из вышеизложенных определений понятия «государство» можно сделать ряд выводов: вопервых, существование государства немыслимо без наличия власти; во-вторых, понятия «государственная власть» и «политическая власть» органично связаны.

Политическая (государственная) власть есть разновидность власти общественной. Термины «государственная власть» и «политическая власть» синонимы. В юридической, философской и политологической литературе встречаются и противники этого отождествления. Они считают, что «политическая власть»- понятие более широкое, чем «государственная власть», ибо первая осуществляется не только государством, но и другими субъектами политической системы общества, ${ }^{6}$ полем действия государственной власти является собственно государство и его органы. ${ }^{7}$ Однако замалчивается тот факт, что на протяжении всей истории существования института государства под его прямым или косвенным воздействием находились везде и всегда все институты гражданского общества, которые либо пестовались и поощрялись им, либо третировались и уничтожались.

В ходе развития мировой и отечественной истории процесс возникновения государства, а с ним и государственной власти, в различных регионах протекал по-разному. Под влиянием этих особен-

\footnotetext{
${ }^{4}$ Словарь русского языка: В 4-х т. / АН СССР, Ин-т русского языка / Под ред. А.П. Евгеньевой. 2 - е изд., испр. и доп. [Текст] - М.: Русский язык. 1981. Т. 1. А-й. 1981. С. 339.

${ }_{5}^{5}$ Российская юридическая энциклопедия. [Текст] - М.: Издательский Дом «ИНФРА - М», 1999. Х. С. 207.

${ }^{6}$ Дмитриев, Ю.А. Соотношение понятий политической и государственной власти в условиях формирования гражданского общества [Текст] / Ю.А. Дмитриева // Государство и право. - 1994. - № 7. - С. 33-34.

7 Там же. - C. 34.
}

ностей зарождения государства и государственной власти по мере смены общественно-экономических формаций, политических режимов и в силу особенностей формы правления и государственного устройства государства, формировались точки зрения государственно-правовой и философской мысли на сущность понятий «власть» и «государственная власть».

Как отмечает В.Е. Чиркин, государство представитель общества, и его главная задача - выполнение «общих дел», такое управление обществом, чтобы наряду с саморегулированием жизнь в нем подчинялась определенным (предполагается - совместно проработанным) правилам, не допускающим анархии и распада общества. Насилие - не главная сторона в его деятельности, хотя угроза принуждения представляет собой потенциальное предупреждение о последствиях нарушения правил. ${ }^{8}$ Однако общим целям в обществе с различными социальными слоями, с их разными интересами нельзя служить абстрактно. Представляется, что любое государство, в том числе и современное, всегда и везде следует интересам определенного класса (социального слоя), удовлетворяя его потребности, по возможности, конечно, удовлетворяя интересы и всех прочих классов, социальных слоев общества. В высокоразвитых государствах этот класс (властьимущий) может составлять относительное большинство населения, в развивающихся странах он всегда представляет собой ничтожное меньшинство.

По мнению участников «круглого стола» журнала «Государство иправо», который состоялся в 2001 году, «...в России нынешней мы видим «недоправовое» (но конституционно-декларированное) государство и «недогражданское общество»...», 9 тем не менее, «государство (государственный аппарат) выступает в качестве управляющей системы по отношению к гражданскому обществу как управляемой системе. Вместе с тем гражданское общество функциониру-

\footnotetext{
8 Чиркин, В.Е. Переходное постсоциалистическое государство: содержание и форма [Текст] / В.Е. Чиркин // Государство и право. - 1997. - №1. - С. 7.

${ }^{9}$ Гражданское общество, правовое государство и право («круглый стол» журналов «Государство и право» и «Вопросы философии») [Текст] // Государство и право. - 2002. - № 1. - C. 14.
} 
ет как саморегулирующаяся социальная система, детерминирующая государство». ${ }^{10}$

В связи с вышеизложенным, государство представляет собой организацию публичной власти, необходимую как для достижения удовлетворения интересов и потребностей отдельных классов, так и выполнения общих дел, вытекающих из природы всякого общества. Таким образом, понятие «государственная власть» персонифицировано, содержит действующий субъект- государство в лице его органов, которым народ делегирует принадлежащую себе власть (ст. 3 Конституции Российской Федерации). Главное регулирующее воздействие конституционного законодательства можно определить как организацию и деятельность государственной власти, установление правовых рамок деятельности в гражданском обществе. ${ }^{11}$

В современной отечественной научной литературе имеется, по крайней мере, четыре подхода в определении понятия «государственная власть», находящих своё воплощение в области конкретных правоотношений, особенно при помощи нормотворчества: как системы государственных органов; как особого волевого отношения; как набора полномочий; как функции.

Сторонники понимания государственной власти как системы полномочий отмечают, что «подтверждением характеристик государственной власти как совокупности властных полномочий служит практика реализации федеративных отношений в Российской Федерации. Разделение власти на федеральном уровне есть ни что иное, как разделение компетенции. Споры о компетенции (ст. 125 ч. 3 Конституции России) - это споры об объеме властных полномочий того или иного органа, то есть опять о разделении власти». ${ }^{12}$ В этой связи Н.А. Ушаков указывает на обязывающий характер государственной власти, образуемой органами государства в совокупности, формирующими государство как таковое. ${ }^{13}$

10 Там же. - C. 18-19.

${ }^{11}$ Макаров, О.В. Соотношение права и государства [Текст]/ О.В. Макаров // Государство и право. - 1995. - № 5. - С. 19.

${ }^{12}$ Мальй, А.Ф. Государственная власть как правовая категория [Текст] / А.Ф. Малый // Государство и право. - 2001. - № 3. - C. 98.

13 Ушаков, Н.А. Государство в системе международноправового регулирования. Уч. пособие. [Текст]-М., 1997. - C. 14,15 .
Коллектив авторов под руководством А.И. Бобылева определяет государственную власть как совокупность полномочий, реализуемых специально учрежденными органами, осуществляющими воздействие на различные сферы деятельности общества, обладающую возможностью публичного принуждения с применением юридических средств. ${ }^{14}$

А.Ф. Малый рассматривает государственную власть как конституционно-правовую категорию одновременно в двух значениях: с одной стороны, как совокупность властных государственных полномочий, а с другой - как совокупность (систему) государственных органов. ${ }^{15}$

По мнению приверженцев функционального понимания власти, сами органы власти и акты, ими принимаемые, являются функциями власти подобно тому, как и вообще все функции, осуществляемые отдельными органами живого. ${ }^{16}$ Власть рассматривается сторонниками данной концепции как необходимая функция по руководству, управлению и координации волевых действий людей любого коллектива. ${ }^{17}$

В.М. Хвостов различал такие функции власти, как законодательство, суд и управление; ${ }^{18}$ власть у него не отождествляется с функцией, а лишь говорится о функциях (направлениях деятельности) верховной власти. Однако функция, понимаемая как направление деятельности государственного органа, может раскрыть лишь содержание направления деятельности, но не содержание власти вообще.

В свою очередь, рассматривал государственную власть и как функцию, и как правоотношение Л.И. Петражицкий, подразумевая под специальными властями соответственные специальные, ограниченные определенною областью поведения,

${ }^{14}$ Бобылев, А.И., Горшкова, Н.Г., Ивакин, В.И. Исполнительная власть в России: теория и практика ее осуществления. [Текст] - М., 2003. - С. 24.

${ }^{15}$ Малый, А.Ф. Государственная власть как правовая категория [Текст] / А.Ф. Малый // Государство и право. - 2001. - № 3. - C. 99.

${ }^{16}$ Коркунов, Н.М. Лекции по общей теории права. [Текст] СПб., 1894. С. 250.

17 Манов, Г.Н. Признаки государства: новое прочтение / Политические проблемы теории государства. [Текст] - М., 1993. - C. 42.

${ }_{18}$ Хвостов, В.М. Общая теория права. [Текст] - СПб., М., Варшава, Вильно, 1914. С. 15 и след. 


\section{Политика и общество $7(103) \cdot 2013$}

обязанности одних - права других, ${ }^{19}$ отмечая, что субъекты власти (верховной и подчиненной) осуществляют последнюю через функции издания законов, исполнительную и судебную. ${ }^{20}$

В.Е. Чиркин рассматривал власть как социальное волевое отношение, в котором одной из сторон является особый политический субъект - государство (его орган, должностное лицо), ${ }^{21}$ отмечая, что государственная власть принадлежит государству, его органам, но ее реальные рычаги находятся в руках узкой группировки. ${ }^{22}$ В этом случае власть отождествляется с совокупностью (набором) полномочий, поскольку система государственных органов или особое волевое отношение (понимаемые как власть) не могут принадлежать государству и системе его органов (при таком предположении налицо тавтология).

В контексте статьи 10 Конституции России очевидно, что государственная власть отождествляется с реализацией властных полномочий, но никак не с самими органами власти (орган не может «осуществлять» сам себя). Общая логика построения конституционных норм позволяет говорить о том, что власть в конституционно-правовом смысле рассматривается неоднозначно. Так, ч. 4 ст. 3 Конституции России содержит положение о запрете присвоения или захвата власти в стране (в данной статье понятие «власть» отождествляется с понятием «полномочие»). Статья 18 Конституции подразумевает, что власть - это органы, указывая, что деятельность власти определяется правами и свободами человека и гражданина.

Данные определения понятия государственной власти позволяют выявить назначение государственной власти и ее роль в регулировании общественных отношений. В настоящее время такое важное и основополагающее конституционное понятие как «государственная власть» не имеет четко выраженного определения. Использование термина «государственная власть» в нор-

\footnotetext{
${ }^{19}$ Петражицкий, Л.И. Теория права и государства в связи с теорией нравственности. Т. 1. [Текст] - СПб., 1907. С. 192.

${ }^{20}$ Там же. - С. 207.

${ }_{21}$ Чиркин, В.Е. Элементы сравнительного государствоведения. [Текст]- М., 1994. С. 16.

22 Чиркин, B.E. Переходное постсоциалистическое государство: содержание и форма [Текст] / В.Е. Чиркин // Государство и право. - 1997. - №1. - С. 8.
}

мотворчестве указывает на то, что законодатель в различных нормативно-правовых актах неоднозначно трактует содержание данного понятия. В то же время, совершенно ясно, что не всякое научное определение можно формализовать и использовать в категориальном аппарате и, прежде всего, в законотворческом процессе (например, понимание государственной власти как особого волевого отношения вряд ли возможно изложить с помощью правовых категорий, а определение власти как функции имеет большую ценность лишь в общетеоретическом плане).

Представляется, что наиболее правильным вариантом формализации понятия «государственная власть» является отождествление его со свойством государственных органов, обладающих совокупностью государственно-властных полномочий, так как именно посредством реализации данного свойства государственного аппарата народ осуществляет принадлежащую ему власть (статья 3 Конституции России). В связи с этим возникает вопрос о содержании понятия «полномочия», которое следует рассматривать как в широком смысле, так и с точки зрения его конституционного использования.

В отечественной литературе данное понятие рассматривается в тесной связи с такими понятиями как «предмет ведения» и «компетенция». По мнению И.В. Гранкина, в правовой литературе под компетенцией понимается совокупность предметов ведения, прав и обязанностей. ${ }^{23}$ Однако А.Ф. Малый считает, что наиболее правильным является понимание компетенции через два ее элемента: предметы ведения и полномочия. ${ }^{24}$ Предметы ведения, в свою очередь, рассматриваются как сферы общественной жизни, в которой действует конкретный государственный орган, а права и обязанности - как пределы его возможностей в определенной сфере общественной жизни. ${ }^{25}$

${ }^{23}$ Гранкин, И.В. Компетенция законодательных органов краев, областей и городов федерального значения. [Текст] Интернет: http://niiss.ru/Publications/Mag/12/compet.htm.

${ }^{24}$ Maльй, А.Ф. Государственная власть как правовая категория [Текст] / А.Ф. Малый // Государство и право. -2001. - № 3. - C. 96.

${ }^{25}$ Авакьян, С.А. Правовое регулирование деятельности Советов. [Текст] М., 1980; Кутафин, О.Е., Шеремет, К.Ф. Компетенция местных Советов. [Текст] - М., 1982; Фадеев, В.И. Муниципальное право России. [Текст] - М., 1994. 
В данном случае под компетенцией законодатель понимает совокупность полномочий по определенным предметам ведения. Конкретное полномочие органа, являясь юридически закрепленным за ним правом, одновременно представляет собой обязанность по принятию правовых актов и иных действий, направленных на исполнение поставленных перед данным органом задач и функций. Как метко отметила И.А. Умнова, «к предметам ведения ... относятся ... вопросы, в рамках которых субъект реализует свою власть». ${ }^{26}$

Авторы Конституции отказались от более широкого использования термина «компетенция» в целях отделения института предметов ведения от прав и обязанностей органов. При таком подходе конкретные права и обязанности представлены как полномочия, составляющие компетенцию вместе с предметами ведения. Некоторые ученые необоснованно противопоставляют понятия «предметы ведения» и «компетенция». По их мнению, если первое понятие служит для обозначения отношений между Федерацией и ее субъектами, то второе - для обозначения отношений между отдельными видами федеральных органов, органов субъектов Федерации и между органами власти Федерации и ее субъектов. ${ }^{27}$

В Российской Конституции понятие «полномочия» понимается трояко: во-первых, как характеристика прав и обязанностей конкретного органа (например, ст. 83); во-вторых, как характеристика совокупных прав и обязанностей Российской Федерации (статьи 73 и 79); в-третьих, как конкретные полномочия (например, часть 4 статьи 3). В данном случае компетенция рассматривается не как совокупность предметов ведения и полномочий, а сформулирована как конкретное полномочие. Однако, в статьях 5 (ч. 3) и 11 (ч. 3) идет речь о разграничении предметов ведения и полномочий между федеральными и региональными органами государственной власти, то есть «предметы ведения» выделены как самостоятельное понятие.

Существуют различные подходы в определении содержания понятия системы государствен-

\footnotetext{
${ }^{26}$ Умнова, И.А. Конституционные основы современного российского федерализма. [Текст] - М., 1998. - С. 160.

27 Федерация в зарубежных странах. [Текст] - М., 1993. C. $17-18$.
}

ной власти в России. ${ }^{28}$ [24, с. $29-41 ; 25$, с. 31-37; 26] Ряд ученых-правоведов рассматривают термин «система государственной власти», опираясь на часть 3 статьи 5 Конституции Российской Федерации, согласно которой федеративное устройство страны основано на ее государственной целостности, единстве системы государственной власти, разграничении предметов ведения и полномочий между органами государственной власти России и ее субъектов.

В научной литературе довольно активно используются для обозначения системы государственных органов и системы государственной власти термины «законодательная власть», «судебная власть», «исполнительная власть», ${ }^{29}$ что обусловлено в основном лексическими особенностями языка. При определении системы государственной власти как совокупности законодательной (представительной), исполнительной, судебной власти через призму принципа разделения властей необходимо учитывать, что в подобном случае функционирует целостная конструкция построения органов, и в этом случае ветви власти не представляют собой совокупности взаимосвязанных элементов. Рассмотрение отдельных элементов не позволяет раскрыть системные связи в их взаимоотношениях. Например, Конституционный Суд России, являясь самостоятельным судебным органом, не возглавляет систему конституционного контроля.

Провозглашенное единство судебной системы в ст. 2 Федерального конституционного закона «О судебной системе Российской Федерации» носит декларативный характер. Как отмечают С.В. Бородин и В.Н. Кудрявцев: «...составители проекта Конституции 1993 г. находились под влиянием прежней практики разобщения судебной системы

28 Дахин, А.В. Система государственной власти в России: феноменологический транзит [Текст] / А.В. Дахин // Полис. - 2006. - № 3. - С. 29-41; Мартышин, О.В. Идейно-политические основы современной российской государственности [Текст] / О.В. Мартышин // Государство и право. - № 10. C. 31-37; Кочев, B.A. Государственная власть в Российской Федерации. Конституционно-правовые основы корреляции. [Текст] - Пермь: изд-во Пермского ун-та, 2000.

${ }^{29}$ Салищева, Н.Г., Хаманева, Н.Ю. Исполнительная и судебная ветви власти: соотношение и взаимодействие [Текст] / Н.Г. Салищева, Н.Ю. Хаманева // Государство и право. 2000. - № 1. - С. 5-11; Исполнительная власть в Российской Федерации. Проблемы развития / Отв. ред. д-р юрид. наук Бачило И.Л. [Текст] - М.: «Юристъ». 1998. 


\section{Политика и общество $7(103) \cdot 2013$}

... в действительности в России три самостоятельные, не связанные между собой судебные системы: 1) Конституционный суд РФ и конституционные (уставные) суды субъектов Федерации; 2) Верховный суд РФ с системой нижестоящих судов общей юрисдикции; 3) Высший арбитражный суд с системой нижестоящих арбитражных судов...». ${ }^{30}$

Однако, утверждение, что Конституционный Суд России и конституционные (уставные) суды субъектов Федерации представляют собой самостоятельную систему, неверное, так как согласно действующему законодательству не предусмотрено какое-либо совместное участие названных судов в конституционном (уставном) судопроизводстве. В отличие от вышеназванных судов Верховный Суд страны, как и в советский период, является судом второй инстанции по всем гражданским и уголовным делам, рассмотренным судами субъектов, венчая систему судов общей юрисдикции.

В научной литературе дается ряд довольно точных и четких определений судебной власти. Так, И.Л. Петрухин понимает под судебной властью самостоятельную и независимую ветвь государственной власти, созданную для разрешения на основе закона социальных конфликтов между государствами и гражданами, самими гражданами, юридическими лицами; контроля за конституционностью законов; защиты прав граждан в их взаимоотношениях с органами исполнительной власти и должностными лицами; контроля за соблюдением прав граждан при расследовании преступлений и проведении оперативно-розыскной деятельности (ОРД); установления наиболее значимых юридических фактов. ${ }^{31}$ Другие авторы в определении понятия системы судебной власти подчеркивают ее самостоятельность от других ветвей власти и произвола вообще, независимость от кого или чего-либо кроме закона.

Система представительной (законодательной) власти в России определена Конституцией еще более размыто и неопределенно. Взаимодействие

\footnotetext{
${ }^{30}$ Бородин С.В., Кудрявиев В.Н. О судебной власти в России [Текст] / С.В. Бородин, В.Н. Кудрявцев // Государство и право. - 2001. - № 10. - С. 22.

${ }^{31}$ Петрухин, И.Л. Проблема судебной власти в современной России [Текст] / И.Л. Петрухин // Государство и право. 2000. - № 7. - С. 15-21.
}

федерального и региональных парламентов ограничено правом законодательной инициативы последних, участия в обсуждении законопроектов по предметам совместного ведения, и возможностью их роспуска путем принятия Федеральным Собранием соответствующего закона.

Исполнительную власть можно определить как самостоятельную и независимую в рамках принципа разделения властей ветвь государственной власти, носящую всеобъемлющий, предметный и организующий характер, структурированную в единую систему органов исполнительной власти, обеспечивающих исполнение и реализацию законов в законно установленных формах, порядке и методами в пределах своих полномочий.

В связи с вышеизложенным, можно сделать ряд выводов:

1) Государственная власть в Российской Федерации является свойством государственных органов, обладающих совокупностью государственных властных полномочий.

2) Конституция Российской Федерации и действующее законодательство не содержит единообразного понимания государственной власти.

3) Разделение государственной власти на законодательную (представительную), исполнительную и судебную достаточно условное, в Конституции страны упоминаются лишь системы исполнительной и судебной власти, в которые не включены ряд субъектов власти, в том числе и органы местного самоуправления, обладающие огромными властными полномочиями. Судебная власть подразделена на отдельные самостоятельные в организационном и правовом плане участки. Совершенно самостоятельную роль играет важный высший судебный орган страны - Конституционный Суд России.

4) Система государственной власти в России обладает признаком единства, ${ }^{32}$ не исключающим самостоятельности различных государственных органов, со строго определенными полномочиями, которые могут перераспределяться между субъектами, но в своей совокупности составляют неизменный набор и регулируют весь объем общественных отношений.

\footnotetext{
32 Барииц, И.Н. О единстве государственной власти в Российской Федерации [Текст] / И.Н. Барциц // Законодательство. - 2001. - № 9. - С. 37-44.
} 
Как метко выразился В.Е. Чиркин, разделение властей требует единства государственной политики, единства действий всех ветвей по принципиальным вопросам общественного развития, а единство власти не исключает прозаического разделения труда между различными органами государственной власти. ${ }^{33}$

\section{Библиография:}

1. Байтин, М.И. Государство и политическая власть. [Текст] - Саратов. - 1972. - С. 89.

2. Кокорев, Р.С. Понятие и характерные черты государства как субъекта международного права [Текст] / Р.С. Кокорев // Государство и право. - 2005. - № 12. - С. 71-79.

3. Ожегов, С.И. Словарь русского языка: ок. 57000 слов / Под ред. чл.-корр. АН СССР Н.Ю. Шведовой. 20-е изд., стереотип. [Текст] - М.: Русский язык, 1988. С. 115-116.

4. Словарь русского языка: В 4-х т. / АН СССР, Ин-т русского языка / Под ред. А.П. Евгеньевой. 2 - е изд., испр. и доп. [Текст] - М.: Русский язык. 1981. Т. 1. А-й. 1981. С. 339.

5. Российская юридическая энциклопедия. [Текст] - М.: Издательский Дом «ИНФРА - М», 1999. X. C. 207.

6. Дмитриев, Ю.А. Соотношение понятий политической и государственной власти в условиях формирования гражданского общества [Текст] / Ю.А. Дмитриева // Государство и право. 1994. - № 7. - С. 33-34.

7. Чиркин, В.Е. Переходное постсоциалистическое государство: содержание и форма [Текст] / В.Е. Чиркин // Государство и право. - 1997. №1. - С. 7.

8. Гражданское общество, правовое государство и право («круглый стол» журналов «Государство и право» и «Вопросы философии») [Текст] // Государство и право. - 2002. - № 1. - С. 14.

9. Макаров, О.В. Соотношение права и государства [Текст] / О.В. Макаров // Государство и право. - 1995. - № 5. - С. 19.

\footnotetext{
33 Чиркин, B.E. Конституционное право зарубежных стран. [Текст] - М., 1999. - С. 145; Самонова, Е.А. Исполнительная власть в постсоветских государствах (на примере России, Эстонии и Кыргызстана) [Текст] / Е.А. Самонова // Полис. - 2003. - № 3. - С. 78-89.
}

10. Малый, А.Ф. Государственная власть как правовая категория [Текст] / А.Ф. Малый // Государство и право. - 2001. - № 3. - С. 98.

11. Ушаков, Н.А. Государство в системе международно-правового регулирования. Уч. пособие. [Текст] - М., 1997. - С. 14,15.

12. Бобылев, А.И., Горшкова, Н.Г., Ивакин, В.И. Исполнительная власть в России: теория и практика ее осуществления. [Текст] - М., 2003. - С. 24.

13. Коркунов, Н.М. Лекции по общей теории права. [Текст] - СПб., 1894. С. 250.

14. Манов, Г.Н. Признаки государства: новое прочтение / Политические проблемы теории государства. [Текст] - М., 1993. - С. 42.

15. Хвостов, В.М. Общая теория права. [Текст] СПб., М., Варшава, Вильно, 1914. С. 15 и след.

16. Петражицкий, Л.И. Теория права и государства в связи с теорией нравственности. Т. 1. [Текст] - СПб., 1907. С. 192.

17. Чиркин, В.Е. Элементы сравнительного государствоведения. [Текст] - М., 1994. С. 16.

18. Гранкин, И.В. Компетенция законодательных органов краев, областей и городов федерального значения. [Текст] Интернет: http://niiss. ru/Publications/Mag/12/compet.htm.

19. Авакьян, С.А. Правовое регулирование деятельности Советов. [Текст] М., 1980.

20. Кутафин, О.Е., Шеремет, К.Ф. Компетенция местных Советов. [Текст] - М., 1982.

21. Фадеев, В.И. Муниципальное право России. [Текст]-М., 1994.

22. Умнова, И.А. Конституционные основы современного российского федерализма. [Текст] М., 1998. - С. 160.

23. Федерация в зарубежных странах. [Текст] М., 1993. - С. 17-18.

24. Дахин, А.В. Система государственной власти в России: феноменологический транзит [Текст] / А.В. Дахин // Полис. - 2006. - № 3. - С. 29-41.

25. Мартышин, О.В. Идейно-политические основы современной российской государственности [Текст] / О.В. Мартышин // Государство и право. - № 10. - С. 31-37.

26. Кочев, В.А. Государственная власть в Российской Федерации. Конституционно-правовые основы корреляции. [Текст] - Пермь: изд-во Пермского ун-та, 2000.

27. Салищева, Н.Г., Хаманева, Н.Ю. Исполнительная и судебная ветви власти: соотноше- 


\section{Политика и общество 7 (103) • 2013}

ние и взаимодействие [Текст] / Н.Г. Салищева, Н.Ю. Хаманева // Государство и право. - 2000. - № 1. - С. 5-11.

28. Исполнительная власть в Российской Федерации. Проблемы развития / Отв. ред. д-р юрид. наук Бачило И.Л. [Текст] - М.: «Юристъ». 1998.

29. Бородин С.В., Кудрявцев В.Н. О судебной власти в России [Текст] / С.В. Бородин, В.Н. Кудрявцев // Государство и право. - 2001. - № 10. - C. 22.

30. Петрухин, И.Л. Проблема судебной власти в современной России [Текст] / И.Л. Петрухин // Государство и право. - 2000. - № 7. - С. 15-21.

31. Барциц, И.Н. О единстве государственной власти в Российской Федерации [Текст] / И.Н. Барциц // Законодательство. - 2001. № 9. - С. 37-44.

32. Чиркин, В.Е. Конституционное право зарубежных стран. [Текст] -М., 1999. - С. 145.

33. Самонова, Е.А. Исполнительная власть в постсоветских государствах (на примере России, Эстонии и Кыргызстана) [Текст] / Е.А. Самонова // Полис. - 2003. - № 3. - С. 78-89.

\section{References (transliteration):}

1. Baytin, M.I. Gosudarstvo i politicheskaya vlast'. [Tekst] - Saratov. - 1972. - S. 89.

2. Kokorev, R.S. Ponyatie i harakternye cherty gosudarstva kak sub'ekta mezhdunarodnogo prava [Tekst] / R.S. Kokorev // Gosudarstvo i pravo. 2005. - № 12. - S. 71-79.

3. Ozhegov, S.I. Slovar' russkogo yazyka: ok. 57000 slov / Pod red. chl.-korr. AN SSSR N.Yu. Shvedovoy. 20-e izd., stereotip. [Tekst] - M.: Russkiy yazyk, 1988. S. 115-116.

4. Slovar' russkogo yazyka: V 4-h t. / AN SSSR, In-t russkogo yazyka / Pod red. A.P. Evgen'evoy. 2 e izd., ispr. i dop. [Tekst] - M.: Russkiy yazyk. 1981. T. 1. A-y. 1981. S. 339.

5. Dmitriev, Yu.A. Sootnoshenie ponyatiy politicheskoy i gosudarstvennoy vlasti v usloviyah formirovaniya grazhdanskogo obschestva [Tekst] / Yu.A. Dmitrieva // Gosudarstvo i pravo. - 1994. - № 7. - S. 33-34.

6. Chirkin, V.E. Perehodnoe postsocialisticheskoe gosudarstvo: soderzhanie i forma [Tekst] / V.E. Chirkin // Gosudarstvo i pravo. - 1997. - №1. - S. 7.
7. Makarov, O.V. Sootnoshenie prava i gosudarstva [Tekst] / O.V. Makarov // Gosudarstvo i pravo. 1995. - № 5. - S. 19.

8. Malyy, A.F. Gosudarstvennaya vlast" kak pravovaya kategoriya [Tekst] / A.F. Malyy // Gosudarstvo i pravo. - 2001. - № 3. - S. 98.

9. Ushakov, N.A. Gosudarstvo v sisteme mezhdunarodno-pravovogo regulirovaniya. Uch. posobie. [Tekst] - M., 1997. - S. 14,15.

10. Bobylev, A.I., Gorshkova, N.G., Ivakin, V.I. Ispolnitel'naya vlast' $\mathrm{v}$ Rossii: teoriya i praktika ee osuschestvleniya. [Tekst] - M., 2003. - S. 24.

11. Korkunov, N.M. Lekcii po obschey teorii prava. [Tekst] - SPb., 1894. S. 250.

12. Manov, G.N. Priznaki gosudarstva: novoe prochtenie / Politicheskie problemy teorii gosudarstva. [Tekst] - M., 1993. - S. 42.

13. Hvostov, V.M. Obschaya teoriya prava. [Tekst] SPb., M., Varshava, Vil'no, 1914. S. 15 i sled.

14. Petrazhickiy, L.I. Teoriya prava i gosudarstva $\mathrm{v}$ svyazi s teoriey nravstvennosti. T. 1. [Tekst] SPb., 1907. S. 192.

15. Chirkin, V.E. Elementy sravnitel'nogo gosudarstvovedeniya. [Tekst] - M., 1994. S. 16.

16. Grankin, I.V. Kompetenciya zakonodatel'nyh organov kraev, oblastey i gorodov federal'nogo znacheniya. [Tekst] Internet: http://niiss.ru/Publications/Mag/12/compet.htm.

17. Avak'yan, S.A. Pravovoe regulirovanie deyatel'nosti Sovetov. [Tekst] M., 1980.

18. Kutafin, O.E., Sheremet, K.F. Kompetenciya mestnyh Sovetov. [Tekst] - M., 1982.

19. Fadeev, V.I. Municipal'noe pravo Rossii. [Tekst] - M., 1994.

20. Umnova, I.A. Konstitucionnye osnovy sovremennogo rossiyskogo federalizma. [Tekst] - M., 1998. - S. 160.

21. Dahin, A.V. Sistema gosudarstvennoy vlasti v Rossii: fenomenologicheskiy tranzit [Tekst] / A.V. Dahin // Polis. - 2006. - № 3. - S. 29-41 .

22. Martyshin, O.V. Ideyno-politicheskie osnovy sovremennoy rossiyskoy gosudarstvennosti [Tekst] / O.V. Martyshin // Gosudarstvo i pravo. - № 10. - S. 31-37.

23. Kochev, V.A. Gosudarstvennaya vlast` v Rossiyskoy Federacii. Konstitucionno-pravovye osnovy korrelyacii. [Tekst] - Perm': izd-vo Permskogo un-ta, 2000.

24. Salischeva, N.G., Hamaneva, N.Yu. Ispolnitel'naya i sudebnaya vetvi vlasti: sootnosh- 
enie i vzaimodeystvie [Tekst] / N.G. Salischeva, N.Yu. Hamaneva // Gosudarstvo i pravo. - 2000. - № 1. - S. 5-11.

25. Borodin S.V., Kudryavcev V.N. O sudebnoy vlasti v Rossii [Tekst] / S.V. Borodin, V.N. Kudryavcev // Gosudarstvo i pravo. - 2001. - № 10. - S. 22.

26. Petruhin, I.L. Problema sudebnoy vlasti v sovremennoy Rossii [Tekst] / I.L. Petruhin // Gosudarstvo i pravo. - 2000. - № 7. - S. 15-21.
27. Barcic, I.N. O edinstve gosudarstvennoy vlasti v Rossiyskoy Federacii [Tekst] / I.N. Barcic // Zakonodatel'stvo. - 2001. - № 9. - S. 37-44.

28. Chirkin, V.E. Konstitucionnoe pravo zarubezhnyh stran. [Tekst] -M., 1999. - S. 145.

29. Samonova, E.A. Ispolnitel'naya vlast' v postsovetskih gosudarstvah (na primere Rossii, Estonii i Kyrgyzstana) [Tekst] / E.A. Samonova // Polis. -2003 . - № 3. - S. 78-89. 